\title{
Role of motivational interviewing in type 1 Diabetes Mellitus with sub optimal glycemic control.
}

\author{
1. MBBS, MCPS, FCPS \\ Assistant Professor Developmental \\ Pediatrics \\ $\mathrm{CHICH}$ Multan. \\ 2. MBBS, DCH, FCPS \\ Associate Professor Pediatric \\ Endocrinology \\ $\mathrm{CHICH}$ Multan. \\ 3. MBBS, FCPS \\ Senior Registrar Developmental \\ Pediatrics \\ $\mathrm{CHICH}$ Multan. \\ 4. MBBS, FCPS \\ Senior Registrar Pediatric \\ Endocrinology \\ $\mathrm{CHICH}$ Multan \\ Correspondence Address: \\ Dr. Erum Afzal \\ Department of Developmental \\ Pediatrics \\ $\mathrm{CHICH}$ Multan. \\ erumafzal@yahoo.com \\ Article received on: \\ 02/09/2020 \\ Accepted for publication: \\ 17/06/2021
}

\begin{abstract}
Erum Afzal' ${ }^{1}$, Waqas Imran Khan ${ }^{2}$, Mohammad Khalid Iqbal ${ }^{3}$, Sidra Anjum ${ }^{4}$
\end{abstract}
\begin{abstract}
Objective: To determine the role of motivational interviewing in better management of diabetes mellitus in children. Study Design: Observational Cross Sectional Study. Setting: Children Hospital \& Institute of Child Health Multan. Period: November 2019 to May 2020. Material \& Methods: Fifty-six poorly controlled follow up diabetic children of 8 to 15 years of both sexes, with HBA1c more than $10 \%$ were included. Their social status, educational status whether studying or not was noted. All patients were advised subcutaneous Insulin according to weight. All children were counselled and motivated for self-care, problem identification and solution, and proper diabetic management by a team consisting of an endocrinologist, a dietitian, a psychologist and a nurse. Glycemic control was assessed using $\mathrm{HbA}_{1 \mathrm{c}}$, at $1^{\text {st }}$ visit, $3^{\text {rd }}$ and $6^{\text {th }}$ month. A decline in $\mathrm{HbA} 1 \mathrm{c}$ by $\geq 1 \%$ was considered for good control of DM, while $\leq 1 \%$ decrease was taken as poor control of DM. Data was analyzed by using SPSS version 20. Result: Out of 56 patients. $50 \%(n=28)$ were females and , $50 \%(n=28)$ were males. $42.9 \%$ $(n=24)$ patients were age ranges between 8 to 11.5 years while $57.1 \%(n=32)$ more than 11.5 to 15 years, with mean age of $11.8 \pm 1.97$ years $28.6 \%$ diabetic children belonged to lower, $57.1 \%$ middle while $14.3 \%$ upper socioeconomic status. $69.4 \%$ children were going to school while $27.6 \%$ were not studying. Good glycemic control was observed in $85.7 \%$ diabetic children which is statistically significant ( $p$-value $<0.001)$. Conclusion: Motivational interview proved to be a good tool for the better outcome of diabetic children, who need both knowledge and practical communication for their management regarding behavioral changes, lifestyle issues and self-management. It must be a part of diabetic management programs.
\end{abstract}

Key words: $\quad$ Diabetes Mellitus, Glycemic Control, Motivational Interviewing.

Article Citation: Afzal E, Khan WI, lqbal MK, Anjum S. Role of motivational interviewing in type 1 Diabetes Mellitus with sub optimal glycemic control. Professional Med J 2021; 28(12):1718-1722. https://doi.org/10.29309/TPMJ/2021.28.12.6053

\section{INTRODUCTION}

Diabetes mellitus (DM) is an endocrine disease leading to high blood glucose due to disturbance in protein, fats and carbohydrate. Complex interaction between genetic and environmental factors is a major contributory factor in the pathogenesis of this disorder. Long standing uncontrolled diabetes results in secondary changes in various vital organs of body leading to high morbidity and mortality as well as high burden on health care system. ${ }^{1,2}$

The prevalence of diabetes is increasing progressively due to numerous factors like rising prevalence of obesity, declining rate of physical activities, and aging. ${ }^{3}$ which are thought to be direct consequences of industrialization. ${ }^{1,4}$ There are two common types of Diabetes Mellitus, Type 1DM and 2DM. The Children and adolescents mostly develop type $1 \mathrm{DM}^{3}$

There are many complications of uncontrolled DM affecting eyes, kidneys heart, and psychosocial health. Beside medical management; life style modification and psychological support are integral parts of its management. ${ }^{5,6}$ Diabetes needs changes in way of life. ${ }^{7}$ Among adults majority of diabetes care is done by the patients themselves (self-care). Diabetes management will only be effective when psychological problems are addressed adequetly. ${ }^{8}$ That's why self-management is very important for diabetic patients. ${ }^{6}$ There are certain limitations in managing DM like cost of insulin injections 
and glucose monitoring strips, diet modification, frequent infections, and hospitalizations. These restrictions will have negative impact on mental health of diabetic patients. And bring out negative feelings (for example misery, uneasiness, outrage, and so on.) which result in poor control of DM and complications in long term. . $^{90,11}$

Motivational interviewing (MI) was developed as an intervention, where the patient's unwillingness in management is an obstacle in management. ${ }^{12}$ $\mathrm{MI}$ is defined by Rollnick and Miller, as a mutual conversation technique that elicits internal motivation and leads to behavior modification goals. ${ }^{13}$ During 1990's many chronic disorders, with behavioral changes were examined using MI. ${ }^{12,14,15,16}$ For diabetic patients especially children and adolescents, $\mathrm{Ml}$ is the best technique that struggle with behavioral changes and help to motivate them for proper management. It may lead to better diabetic control.

Although much data is available to show the effect of $\mathrm{MI}$ in managing DM in adults but there is not sufficient work done for Diabetic children and adolescents. This study was planned to find the effect of $\mathrm{MI}$ in managing pediatric DM.

\section{MATERIAL \& METHODS}

This observational cross sectional study was done in department of Pediatric endocrinology and developmental pediatrics of the children hospital \& institute of child health Multan from May 2019 to May 2020 the study was reviewed and approved by Ethical Committee (01/2020 Ethical Committee/CH and $\mathrm{ICH}$ Multan). Fiftysix follow up diabetic children of 8 to 15 years of both sexes, having $\mathrm{HbA} 1 \mathrm{c}$ more than $10 \%$ were included. The HbA1c of these children was either static or increasing in past 6 months. Patients with HbA1c less than $10 \%$, having any psychological problems, Low cognition, severe debilitating disease and not giving consent were excluded from study. Their social status, educational status whether studying or not was noted. All patients were advised subcutaneous Insulin according to weight.

A multidisciplinary team was made for counseling and Motivational interviewing of each patient, this team included a pediatric endocrinologist, a dietitian, a psychologist and a nurse. Each patient received a 6 months $\mathrm{Ml}$ program of personal counselling sessions lasting approximately 30-45 min during their first visit, weekly for 4 weeks and then monthly for 5 months. At first visit Patient was visited and counseled by this team along with one or both parents. Patient examinations and investigations were done according to national diabetes guidelines. ${ }^{17}$ Glycosylated hemoglobin (HbA1C) level was measured by high-performance liquid chromatography method ${ }^{18}$ on $1^{\text {st }}$ visit, $3^{\text {rd }}$ and $6^{\text {th }}$ months from hospital laboratory. A decline in $\mathrm{HbA} 1 \mathrm{c}$ by $\geq 1 \%$ was considered for good control of DM, while no decline or $\leq 1 \%$ decrease was taken as poor control of DM.

During Ml, team reinforced the patient's selfmotivational behavior, need and intent to modify lifestyle consequently. Participants were encouraged and their issues were discussed and solved. A semi-structured interview of $\mathrm{MI}$ was followed. Along with psychological support, diet advice, and importance of physical activity was emphasized. They were trained about blood glucose monitoring, and hypoglycemia recognition and management. All medicines and glucose monitoring strips were provided during these visits as needed. ${ }^{18}$

Written consent was taken by parents or guardian. No conflict of interest was involved in this study. No financial support was provided by the institution or pharmaceutical company. All the information was recorded on predesigned Performa. Data was anal yzed by using SPSS version 20. Quantitative variables are presented as mean and standard deviation (SD) while qualitative variables are represented as frequency and percentages. Probability value less than or equal to 0.05 is taken as statistically significant.

\section{RESULTS}

Out of 56 patients, $50 \%(n=28)$ were females and, $50 \%(n=28)$ were males. $42.9 \%(n=24)$ patients were age ranges between 8 to 11.5 years while $57.1 \%(n=32)$ more than 11.5 to 15 years, with mean age of 11.8 years (st dev. \pm 1.97 ) Baseline $\mathrm{HbA} 1 \mathrm{c}$ was $10.99 \%$ (St dev \pm 0.49). Basic 
characteristics of patients are given in Table-l. Good glycemic control was observed in $85.7 \%$ $(n=48)$ diabetic children which is statistically significant ( $p$-value $<0.001$ ).

\begin{tabular}{|c|c|c|c|}
\hline \multicolumn{4}{|c|}{$\mathbf{N} \%$} \\
\hline $\begin{array}{l}\text { Age groups } \\
8-11.5 y e a r s \\
>11.5 \text { to15years }\end{array}$ & \multicolumn{3}{|c|}{$\begin{array}{l}24(42.9 \%) \\
32(57.1 \%)\end{array}$} \\
\hline $\begin{array}{l}\text { Sex } \\
\text { Male } \\
\text { Female }\end{array}$ & \multicolumn{3}{|c|}{$\begin{array}{l}28(50 \%) \\
28(50 \%)\end{array}$} \\
\hline $\begin{array}{l}\text { Socioeconomic status } \\
\text { Low } \\
\text { Middle } \\
\text { Upper }\end{array}$ & \multicolumn{3}{|c|}{$\begin{array}{c}16(28.6 \%) \\
32(57.1 \%) \\
8(14.3 \%)\end{array}$} \\
\hline $\begin{array}{l}\text { Patient s Education } \\
\text { Studying } \\
\text { Not studying }\end{array}$ & \multicolumn{3}{|c|}{$\begin{array}{l}40(69.4 \%) \\
16(27.6 \%)\end{array}$} \\
\hline $\begin{array}{l}\text { Diabetic control } \\
\text { Good control } \\
\text { Poor control }\end{array}$ & \multicolumn{3}{|c|}{$\begin{array}{c}48(85.7 \%) \\
8(14.3 \%)\end{array}$} \\
\hline \multicolumn{4}{|c|}{ Table-I. Age (years). Mean \pm SD $11.8 \pm 1.97$} \\
\hline \multirow{2}{*}{ Variables } & \multicolumn{2}{|c|}{ Diabetic Control } & \multirow{2}{*}{ P-Value } \\
\hline & Good & Poor & \\
\hline $\begin{array}{l}\text { Age groups } \\
8-11.5 y e a r s \\
>11.5 \text { to15years }\end{array}$ & $\begin{array}{l}24 \\
24\end{array}$ & $\begin{array}{l}0 \\
8\end{array}$ & 0.008 \\
\hline $\begin{array}{l}\text { Sex } \\
\text { Male } \\
\text { Female }\end{array}$ & $\begin{array}{l}28 \\
20\end{array}$ & $\begin{array}{l}0 \\
8\end{array}$ & 0.004 \\
\hline $\begin{array}{l}\text { Socioeconomic status } \\
\text { Low } \\
\text { Middle } \\
\text { Upper }\end{array}$ & $\begin{array}{c}12 \\
28 \\
8\end{array}$ & $\begin{array}{l}4 \\
4 \\
0\end{array}$ & 0.233 \\
\hline $\begin{array}{l}\text { Patient s Education } \\
\text { Studying } \\
\text { Not studying }\end{array}$ & $\begin{array}{l}38 \\
10\end{array}$ & $\begin{array}{l}2 \\
6\end{array}$ & 0.005 \\
\hline $\begin{array}{r}\text { Table-II. Relationsh } \\
\text { cont }\end{array}$ & $\begin{array}{l}\text { f vari } \\
(N=\end{array}$ & es with & etic \\
\hline
\end{tabular}

Relationship of different variables with diabetic control is given in Table-Il.

\section{DISCUSSION}

The major outcome of this study was that diabetic children receiving $\mathrm{Ml}$ showed improvement in glycemic control. These results are similar to the few randomized control trials done to show positive behavior changes and diabetic control in young children. ${ }^{19,20,21,22}$ Another study shows that $\mathrm{MI}$ interventions yield better results if family is also involved to promote behavior change. The outcome of the disease is not related to the number of sessions, suggesting short $\mathrm{Ml}$ interventions (one to four sessions) have similar effects on behavior change..$^{23}$ Caccavale LJ also describe the role of $\mathrm{Ml}$ in appropriate management of diabetic children. ${ }^{24}$

This study also revealed that the female patients and the children who are involved in study have shown good glycemic control with Ml intervention, while age of the patient has no significant effect after $\mathrm{Ml}$ intervention. While a study done by Rosenbek Minet at al found that younger children have good results after MI intervention, but sex and educational level has no effect. ${ }^{18}$

Limitation of this study is that previously no much work has been done on Ml intervention in Children. Mostly research about MI interventions for glycemic control in adolescents, revealed wellestablished declines in glycemic control.25,26,27 Although $\mathrm{Ml}$ is found to be appropriate approach during adolescence, but the problem recurs often during this transition from childhood into adolescence. ${ }^{28} \mathrm{Ml}$ may be an appropriate approach to promote better management of diabetes during the transition into young adulthood. ${ }^{29}$ More work must be done in children.

\section{CONCLUSION}

MI proved to be a good tool for the better outcome of diabetic children, who need both knowledge and practical communication for their management regarding behavioral changes, lifestyle issues and self-management. It must be a part of diabetic management programs.

\section{Copyright@ 17 June, 2021.}

\section{REFERENCES}

1. Kasper DL, Fauci AS, Hauser SL, Longo DL, Jameson $\mathrm{JL}$, et al. Harrison's principles of internal medicine. (19 ${ }^{\text {th }}$ edn). Mc Graw Hi education, New York, USA. 2015

2. Black JM, Hawks JH, Medical surgical nursing-clinical management for positive outcome. ( $8^{\text {th }}$ edn). Elsevier sanders, United States of America. 2008. 
3. American Diabetes Association. Diagnostics and classification of diabetes mellitus. Diabetes Care. 2014; 37:S81-90.

4. Wild S, Roglic G, Green A, Sicree R, King H. Global Prevalence of Diabetes: Estimates for the year 2000 and projections for 2030. Diabetes Care 2004; 27(5): 1047-1053.

5. Nakash O, Levav I, Aguilar-Gaxiola S, Alonso J, Andrade $\mathrm{L} . \mathrm{H}$, et al. Comorbidity of common mental disorders with cancer and their treatment gap: Findings from the World Mental Health Surveys. Psycho-Oncology 2014; 23(1): 40-51.

6. El-Bassel N, Jemmott JB 3rd, Landis JR, Pequegnat W, Wingood GM, et al. Intervention to influence behaviors linked to risk of chronic diseases: A multisite randomized controlled trial with African American HIV-serodiscordant heterosexual couples. Arch Intern Med 2011; 171(8): 728-736.

7. Douaihy A, Kelly TM, Gold MA. (2014) Motivational Interviewing, A guide for medical trainees. Oxford University Press, New York, USA.

8. Bazzazian S, Besharat MA, Bahrami Ehsan H, Rajab $A$, The moderating role of coping strategies in relationship between illness perception, quality of life and hba1c in patients with Type I diabetes. Iranian Journal of Endocrinology and Metabolism 2010; 12(3): 213-221.

9. Talakoob S, Gozi M, Ghazavi Z, Attari A. Check of effect relaxation on level blood glucose children with diabetes. J Nurs Midwifery 2005; 3(28): 63-69.

10. Mehrabi A, Fata L, Dvazdah Emamy MH, Rajab A, The effectiveness of cognitive-behavioral stress management the orybasedon glycemic control and reduce the emotional problems of patients with diabetes type1. Iranian Journal of Diabetes and Lipid Disorders 2009; 8(2): 103-114.

11. Sadeghi Movahhed F, Molavi P, Sharghi A, Narimani M, Mohammadnia $\mathrm{H}$, et al. On the relationship between coping strategies and mental health of diabetic patients. Journal of Fundamentals of Mental Health 2010; 12(2): 480-487.

12. Rollnick S, Miller WR, Bulter CC, Motivational Interviewing in Health Care, helping patients change behavior. Guilford Press, New York, USA, 2007; p. 3740.

13. Miller, WR. Rollnick, S. Motivational interviewing: Helping people change. 3. New York:
14. Guilford Press. Miller and Rollnick are the founders of Motivational Interviewing. Recently updated, this seminal work presents the Spirit of MI, the core processes of $\mathrm{Ml}$ and several vignettes to demonstrate clinical implementation of the Ml approach 2013.

15. Momtazi S, Nouhravesh M, Taremian F, Musavinasab $\mathrm{N}$ Alcohol use among Iranian high school students. Alcoholism-Clinical and Experimental Research. 2010; 34(8): 106A-106A.

16. Miller WR, Rollnick S. Motivational interviewing: Preparing people for change. ( $3^{\text {rd }}$ edn) Guilford Press, New York, USA. 2013.

17. Kahanovitz, Lindy et al. "Type 1 Diabetes - A Clinical Perspective." Point of care vol. 16,1 (2017): 37-40.

18. Rosenbek Minet \& L. Wagner \& E. M. Lønvig \& J. Hjelmborg \& J. E. Henriksen. The effect of motivational interviewing on glycaemic control and perceived competence of diabetes self-management in patients with type 1 and type 2 diabetes mellitus after attending a group education programme: A randomised controlled trial". Diabetologia 2011; 54:1620-1629.

19. Channon S, Smith VJ, Gregory JW. A pilot study of motivational interviewing in adolescents with diabetes. Arch Dis Child. 2003; 88:680-3.

20. Channon SJ, Huws-Thomas MV, Rollnick S, et al. A multicenter randomized controlled trial of motivational interviewing in teenagers with diabetes. Diabetes Care. 2007; 30:1390-5.

21. Stanger C, Ryan SR, Delhey LM, et al. A multicomponent motivational intervention to improve adherence among adolescents with poorly controlled type 1 diabetes: A pilot study. J Pediatr Psychol. 2013; 38:629-637.

22. Viner RM, Taylor VT, Hey S. Motivational/solutionfocused intervention improves $\mathrm{HbA1c}$ in adolescents with type 1 diabetes. Diabetic Med. 2003; 20:739-42.

23. Channon, S.; Rubak, S. Family-based intervention. In: Naar-King, S.; Suarez, M., editors. Motivational interviewing with adolescents and young adults. New York: Guilford Press; 2011. p. 165-70.

24. Caccavale LJ, Corona R, LaRose JG, Mazzeo SE, Sova $A R$, Bean MK. Exploring the role of motivational interviewing in adolescent patient-provider communication about type-1 diabetes. Pediatr Diabetes. 2019 Mar; 20(2):217-225. 
25. Wang JT, Wiebe DJ, White PC. Developmental trajectories of metabolic control among white, black, and hispanic youth with type 1 diabetes. J Pediatr. $2011 ; 159: 571-6$.

26. Helgeson VS, Snyder PR, Seltman H, Escobar O, Becker D, Siminerio L. Brief report: Trajectories of glycemic control over early to middle adolescence. J Pediatr Psychol. 2010; 35:1161-7.

27. Bryden KS, Peveler RC, Stein A, Neil A, Mayou RA, Dunger DB. Clinical and psychological course of diabetes from adolescence to young adulthood. Diabetes Care. 2001; 24:1536-40.
28. Baer, JS. Peterson, PL. Motivational interviewing for adolescents and young adults. In: Miller, WR. Rollnick, S., editors. Motivational interviewing: preparing people for change-2. New York: The Guildford Press; 2002. p. 320-32.

29. Monaghan M, Hilliard M, Sweenie R, Riekert K. Transition readiness in adolescents and emerging adults with diabetes: The role of patient-provider communication. Curr Diab Rep. 2013; 13:900-8.

\begin{tabular}{|c|l|l|c|}
\hline \multicolumn{3}{|c|}{ AUTHORSHIP AND CONTRIBUTION DECLARATION } \\
\hline No. & \multicolumn{1}{|c|}{ Author(s) Full Name } & \multicolumn{1}{|c|}{ Contribution to the paper } & Author(s) Signature \\
\hline 1 & Erum Afzal & $\begin{array}{l}\text { Literature search, Study } \\
\text { design, Results Disucssion, } \\
\text { Final approval } \\
\text { Data acquisition, Analysis, } \\
\text { Interpretation \& final approval. }\end{array}$ \\
\hline 3 & Waqas Imran Khan & $\begin{array}{l}\text { Mohammad Khalid Iqbal } \\
\text { Introduction, Results, } \\
\text { Discussion \& Final approval. } \\
\text { Introduction, Results, } \\
\text { Discussion \& Final approval. }\end{array}$ \\
\hline 4 & Sidra Anjum & ive \\
\hline
\end{tabular}

